\title{
A case: Acute myocardial infarction in a child due to spider bite
}

\author{
Edmond Laho', Edmond Puca² \\ ${ }^{1}$ Regional Hospital Center of Elbasan, Department of Pediatric, University Alexander Xhuvani, Elbasan, Albania \\ 2 Service of Infectious Diseases, University Hospital Center, Mother Teresa, Tirana, Albania
}

\begin{abstract}
This report presents a case of a ten-years-old girl, who suffered myocardial ischemia following by "black widow" spider bite. A few minutes after the bite, her parents saw a small, black and shiny lesion in insect bite. The clinical signs began about 3-4 hours after the bite. The venom of the Latrodectus mactans "black widow" is toxic, resulting about 5-6 \% fatality rate. The case of a black widow spider bite resulting in myocardial ischemia is very rare and has not been described in a child before this report in Albania. J Microbiol Infect Dis 2014;4(2): 69-71
\end{abstract}

Key words: Spider, black widow, cardiac ischemia

\section{Bir olgu: Örümcek ısırığı ile oluşan bir akut myokard enfarktüsü}

\section{ÖZET}

Bu rapor 10 yaşındaki bir kız çocuğunda karadul isimli örümcek ısırığı sonrası gelişen miyokardial iskeminin olgu olarak sunumudur. Isırıktan birkaç dakika sonrası, kızın ailesi ısırık yerinde küçük, siyah parlak bir lezyon gördü. Klinik belirtiler 3-4 saat sonra başladı. "Karadul" ya da Latrodectus mactans venomu çok toksiktir ve olguların \%5-6'sında ölümcül seyredebilir. Karadul örümceğinin miyokard iskemisiyle seyretmesi çok nadirdir ve şimdiye kadar Arnavutluk'ta çocuklarda rapor edilmemiştir.

Anahtar kelimeler: Örümcek, karadul, kardiyak iskemi

\section{INTRODUCTION}

Spider bites is rare, but they are particularly dangerous to children due to a large dose of venom per body weight. Spiders are insects within Hymenoptera genus. The most toxic spider is the Latrodectus mactans, so-called "black widow" spider.

Its features are black, shiny color with a body of 1 to $5 \mathrm{~cm}$ diameter with legs open and it has a red characteristic hourglass sign on the abdomen. They can be found in the wood piles, and are often encountered when people transport firewood into their houses. They are also found under eaves, in boxes beneath vacant building material, firewood boxes, and outdoor toilets. The venom of the black widow spider is more than ten times as toxic as the venom of the grass rattlesnake. ${ }^{1}$

The venom of the black widow causes a syndrome which called Lactrodectism. It is seen local pain, swelling, erythema in the skin and is observed circulatory collapse, shock, and ischemia in the cardiovascular system and is detected paralysis and tonic-clinic convulsions in the nervous system. The venom of the L. mactans is extremely toxic, resulting less than $5 \%$ fatality rate.

The aim of this report is to present a case of a ten-years-old girl, who suffered myocardial ischemia following a "black widow" spider bite.

\section{CASE}

A 10-years-old girl was walking when she was suddenly bitten in the right foot by a spider. A few minutes after the bite, she told her parents and showed them a small, black and shiny insect. The clinical signs began about 3-4 hours after the bite. The patient initially had symptoms of edema and severe pain at the site of the bite and after she had the general symptoms of weakness, diffuses sweating, and pallor.

Correspondence: Edmond Puca, Service of Infectious Diseases, University Hospital Center, Mother Teresa, Tirana, Albania Email: edmond_puca@yahoo.com 
Approximately 14-15 hours after the bite began more serious symptoms and signs. These signs are vomiting, dyspnea, chill, chest and abdominal pain, especially intense left-sided chest pain. She was admitted to the hospital and the therapy has begun with the corticosteroids, epinephrine and fluids. Her heart rate was 140-150/min. She didn't have a fever. In the second day of the hospitalization, she became hypotensive with blood pressure of $60 / 40 \mathrm{mmHg}$ and chest pain was more intense. After some hours she became oliguric.

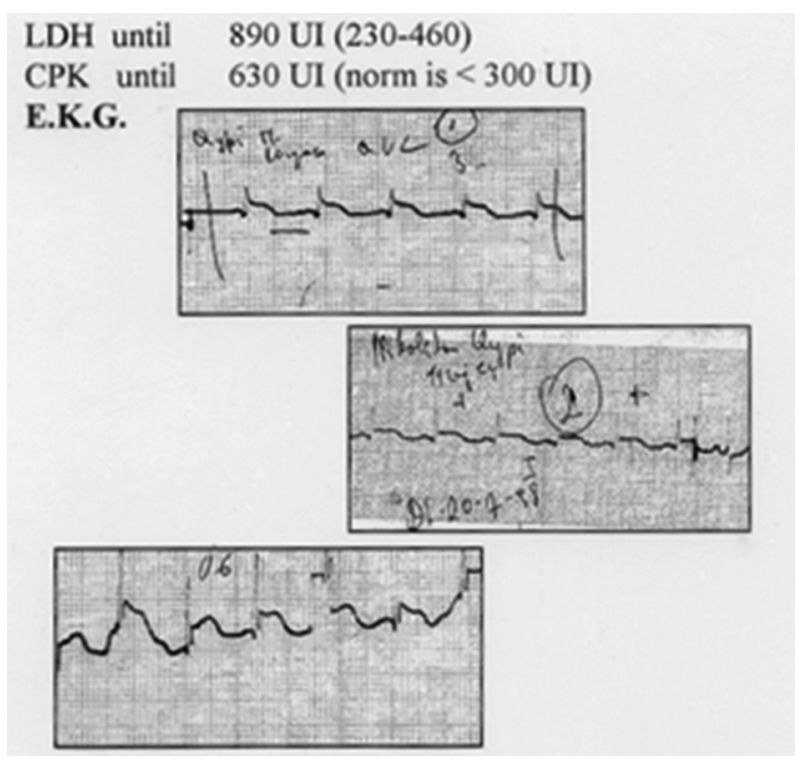

Figure 1. The appearance of electrocardiograpical chancings

The laboratory results were as below: White blood cell (WBC) count of $18 \times 10^{3} / \mathrm{mm}^{3}$ (consist of $43 \%$ segmented neutrophils, $34 \%$ lymphocytes, $12 \%$ eosinophils and $7 \%$ monocytes ) (range 4.0$\left.10.0 \times 10^{3}\right)$ and platelet count of $219 \times 10^{3}$; hemoglobin of $10 \mathrm{~g} / \mathrm{dl}$ (range 12.0-16.5), red blood cells (RBC) of 4,2x106 (range4.2-5.80x106). Her erythrocyte sedimentation rate was $34 \mathrm{~mm} / \mathrm{hr}$ (range $<20$ ). Bilirubinemia was $2.24 \mathrm{mg} / \mathrm{dL}$ (range 0.3-1.2), hepatic transaminases and renal parameters were in normal value. At the second day, the condition of patients was worsened, we asked for additional analysis as lactate dehydrogenase (LDH) was 890 $\mathrm{UI}$ (range 230-460) and creatinine phosphokinase (CPK) was $630 \mathrm{UI}$ (range 300) and EKG which concluded that there was an obvious acute myocardial infarction (Figure 1). The radiology examination of foot and chest were normal. Also the abdominal ultrasonography was normal.
At this time, we suspected myocardial ischemia based on the clinical symptoms as signs of intensive left chest pain, dyspnea, hypotension and tachycardia.

\section{DISCUSSION}

Some researchers claim that one of the most venomous species of black widow spider is living in southern Europe. Between 1999-2006 years, Albanian health records showed 136 cases of spider bites, of which 98 of them (72\%) needed hospital treatment. On literature, at least two people have died from spider bites in Albania. ${ }^{2}$

Spider bites are particularly dangerous to children due to a large dose of venom per body weight. Spiders are insects within Hymenoptera genus. The most toxic spider is the "black widow". ${ }^{3}$

Spider venom is not homogenous chemically. The venom contains amino acids neurotoxic polypeptides and smaller biogenic amines, and sometimes proteolytic enzymes, which relate postsynaptic neuronal membranes, causing a dramatic victory in the acetylcholine's and noradrenaline's neuromuscular connections. ${ }^{4}$

On the other hand, the introduction of this poison in organism will play the role of antigen that will cause the production of a high titer of IgE antibodies to create a responsive a series of anaphylaxis reactions, which will form a picture of rich clinical symptoms. ${ }^{5}$

The pain is added and expands the zone in the abdomen and chest. No rare the hard abdominal pain can simulate the appendicitis clinic. According to literature during the clinical evolution of spider bites have respiratory system touch with laryngospasm, pulmonary edema, and we show cardiovascular tract complications with arrhythmias and myocardial circulatory collapse..$^{5-7}$

We present our case with an acute coronary ischemia. This condition is initially suspected myocarditis pain with growing on the left chest, dyspnea and tachycardia and laboratory changes associated with very high $\mathrm{LDH}$ and $\mathrm{CPK}$ and also following changes of ischemic ECG (Figure 1). These results sustained and we diagnosed acute myocardial ischemia. Physiopathological mechanism of acute myocardial ischemia is explained by the spasm extended myocardial vascular ischemic changes and is accompanied by edema and perivascular responses caused by hyperallergy. ${ }^{6}$ 
In conclusion, the case of a black widow spider bite resulting in myocardial ischemia is very rare and has not been described in a child before this report in Albania. In the literature, there is description of temporary paralysis associated with black widow spider bite.

\section{REFERENCES}

1. Preston-Mafham, Ken and Rob. The Natural History of Spiders. The Crowood Press, Great Britain 1996.
2. Hoxha R. Two Albanians die from black widow spider bites. BMJ. 2006; 5:333(7562):278.

3. Nicholson GM, Graudins A. Antivenoms for the Treatment of Spider Envenomation. Journal of Toxicology 2003;22:35-59.

4. Foelix R. Biology of Spiders. Oxford University Press, New York 1996.

5. Clark RF. The Safety and Efficacy of Antivenin Latrodectus mactans. Clinical Toxicology 2001;39:125-127.

6. Zavalani F, Luka. A Koja .Urgjencat Pediatrike 2011;202-203. (In Albanian)

7. Vetter RS, Isbister GK. Medical aspects of spider bites. Annu Rev Entomol. 2008;53:409-429. 